\title{
4. SEDIMENTARY FABRICS AND VARIATION IN LAMINATION STYLE IN PERU CONTINENTAL MARGIN UPWELLING SEDIMENTS1
}

\author{
Alan E. S. Kemp ${ }^{2}$
}

\begin{abstract}
The fabrics of unconsolidated sediments from the Peru continental margin have been studied using backscattered electron imagery of polished, resin-impregnated samples. These studies reveal a great complexity and heterogeneity of sediment microfacies and demonstrate that this new technique has considerable potential in paleoceanographic and paleoclimatological research. Individual sediment components include planktonic fecal pellets of copepods and anchovies and small terrigenous sediment aggregates produced by benthic activity. Even in intervals where laminae are best preserved, some evidence exists from electron microscope studies for the activity of a benthic meiofauna. Studies of lamination style reveal great variation in composition, spacing, and thickness of laminae. The internal fine-structure of diatom ooze laminae indicates a range of depositional mechanisms from fall out from bloom events to deposition from or reworking by bottom currents. Much of the lamination encountered along the Peruvian margin is a spaced diatom ooze lamination, which is characteristic of sequences having relatively low sedimentation rates and records periodic bloom events. The occurrence of varve-type laminations in sequences older than about 100 k.y. suggests that the Peruvian coastal strip may once have had a regular wet season.
\end{abstract}

\section{INTRODUCTION}

Research that has developed the field of paleoceanography over the last $30 \mathrm{yr}$ has been based largely on "bulk" methods. These include a wide range of micropaleontological, isotopic, and inorganic and organic geochemical techniques that involve subsampling and homogenizing or isolating individual sediment components before analysis. The use of such techniques probably does not incur much loss in resolution when dealing with sequences that have themselves undergone extensive homogenization through bioturbation and for which a potential resolution of "kilo-years" is obtained. However, anaerobic or dysaerobic sediments in which bioturbation is minimal or absent and that have high enough sedimentation rates can yield information of much greater resolution. This increased resolution is both spatial, where primary sedimentary fabrics are preserved, and temporal, where seasonal and even intra-seasonal events are potentially resolvable. Thus, important data about the evolution and development of sediment chemistry, as well as higher resolution time control, are potentially attainable.

In particular, laminated sediments from seasonal upwelling zones provide great potential for high-resolution paleoclimatic study (Soutar and Crill, 1977). However, studies of these sediments have hitherto been based mainly on subsampling of lamina (e.g., Anderson et al., 1987; Baumgartner et al., 1985). The major disadvantage of this approach is that it destroys original sediment fabrics that, as this study shows, contain crucial evidence for interpreting sediment origins, including the preservation of molds of dissolved calcite tests (see Kearsley in Patience et al., this volume). Although some scientists have attempted to impregnate laminated sediments (Calvert, 1966), these attempts have involved examination using optical microscopy, which is severely constrained by resolution and the optical "noise" of the thin section viewed under transmitted light. Reimers (1982) undertook secondary

\footnotetext{
${ }^{1}$ Suess, E., von Huene, R., et al., 1990. Proc. ODP Sci. Results, 112: College Station, TX (Ocean Drilling Program).

2 Department of Oceanography, University of Southampton, Southampton SO9 5NH, United Kingdom.
}

electron imagery in sediment fabric studies of the Peru margin (Reimers, 1982), but her study contains little compositional or porosity information and suffers from topographic noise. Recent developments in the application of scanning electron microscopy (SEM) in the field of back-scattered electron imagery (BSEI) (e.g., Pye and Krinsley, 1984), coupled with the increasing power of linked energy dispersive and image analysis systems, provide the tools for such high-resolution studies of sediments.

The purpose of this study is to integrate the results of high-resolution BSEI of selected late Neogene Peru forearc basin sediments with shipboard and shore-based visual core descriptions and smear slide analysis. Detailed analysis of the sediment components and a descriptive-based classification of lamination type are used as the basis for interpretation of sediment origins.

\section{REGIONAL, OCEANOGRAPHIC, AND SEDIMENTARY CONTEXT}

The waters off Peru are the site of the world's most intense wind-driven coastal upwelling zone. Intense primary production associated with this upwelling produces major fluxes of organic material (Reimers and Suess, 1983; Suess et al., 1986). The rapidly subsiding forearc basins of Peru constitute a unique sedimentary trap that has recorded the effects of coastal upwelling since Miocene time (Suess, von Huene, et al., 1988) (Fig. 1). The Pliocene and Quaternary sediments of the shelf and upper-slope basins are characterized by alternations of dark organic- and diatom-rich muds with paler, organic-poor silty muds (Figs. 2, 3). These meter-scale alternations are ascribed to changes in sea level associated with glacial-interglacial cycles and consequent changes in upwelling intensity and location (Wefer and Suess, and Suess, this volume). The paler, organic-poor intervals are generally olive gray to gray, diatom-bearing, silty or sandy muds with some sands that often contain shell debris (Figs. 2,3). These sediments are usually bioturbated and their original depositional fabrics modified or destroyed.

This study is concerned mainly with the darker organicrich sediments. These comprise dark olive gray to black, laminated to massive, diatomaceous muds and diatom ooze. 


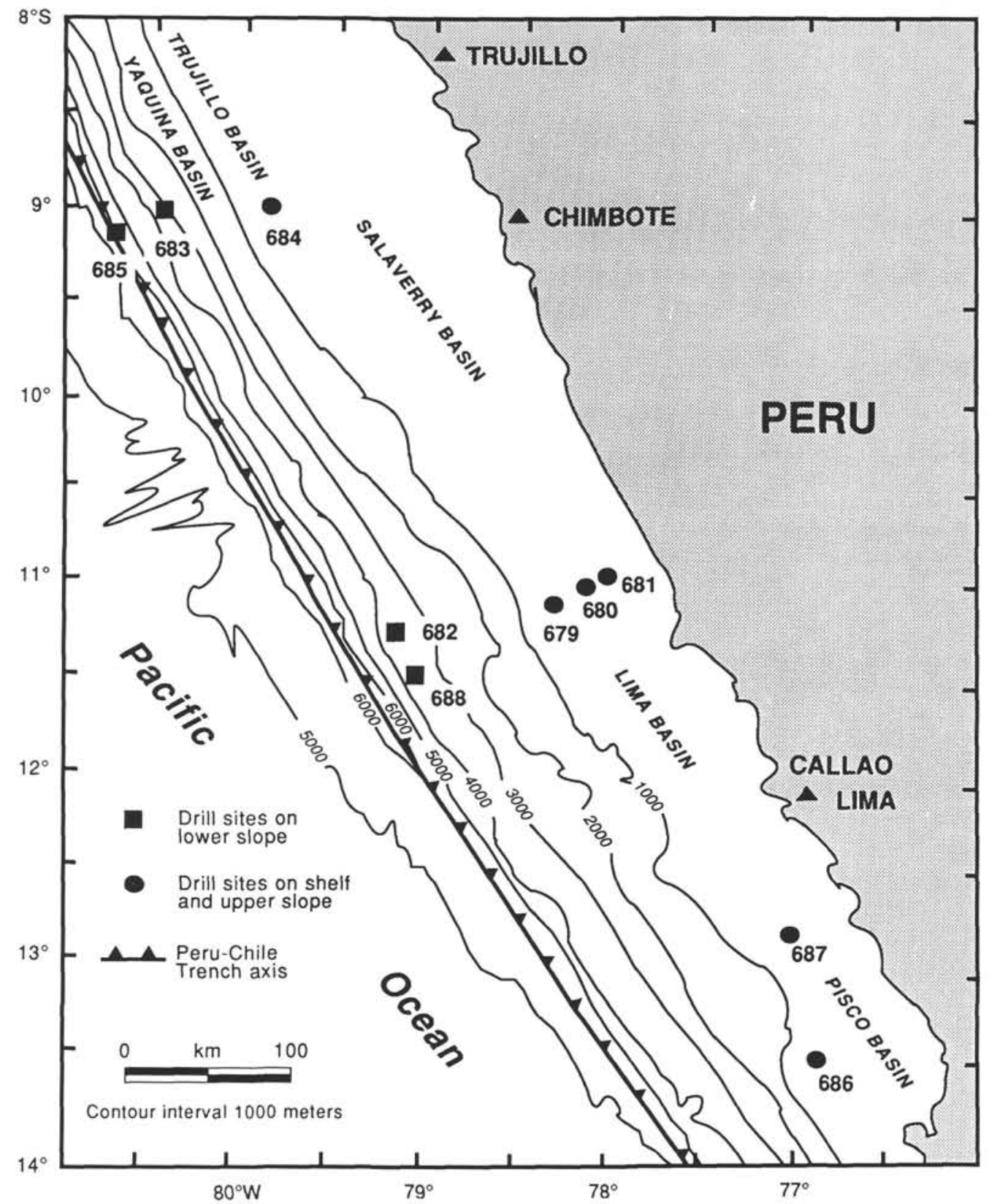

Figure 1. Major forearc basins along the Peru continental margin, showing location of Leg 112 drill sites (from Suess, von Huene, et al., 1988).

Although most of the laminae consist of diatom ooze, their spacing (Figs. 2, 3), thickness, and internal structure varies considerably.

\section{METHODS}

Samples for SEM observation were taken using standard ODP paleomagnetic sample cubes to avoid altering the sediment fabric. Samples were maintained under refrigeration to prevent drying. During processing, subsamples were carefully removed from the sample cubes using scalpel and forceps and were placed in plastic ice-cube trays. These were then positioned in a Logitech vacuum impregnator in batches. The chamber was pumped down to attain a vacuum of about $10^{-6} \mathrm{mb}$ before introducing the pre-evacuated low-viscosity epoxy resin. As evacuation included in effect vacuum drying of the sample, pump-down time ranged up to $36 \mathrm{hr}$. Impregnated samples were then cut and mounted on microscope slides, and the surface polished using a Logitech lapping machine with fine grits, culminating with polishing on an aluminium powder impregnated cloth to maximize the polish. Polished slides were analyzed with a JEOL JSM-840 SEM fitted with a Tracor TN-2000 energy dispersive analysis and imaging system and a solid-state backscattered electron detector. The principles of SEM using BSEI are outlined in Goldstein et al. (1981), while geological applications are discussed in Krinsley et al. (1983) and references therein.

Those unfamiliar with the BSE technique will be helped by a few comments about the way the images displayed in Plates 1 through 5 were produced. BS electrons undergo elastic collisions with the sample. The number of electrons that are back-scattered therefore relates to the atomic number $(\mathrm{Z})$ or, more specifically, the backscatter coefficient of the material with which they collide (see Kearsley in Patience et al., this volume). Thus, high $\mathrm{Z}$ minerals will have a brighter image than lower $\mathrm{Z}$ minerals. The epoxy resin used for impregnation is therefore black in Plates 1 through 6. Much of the contrast displayed in the images relates to differences in porosity, with open-framework diatom ooze layers appearing darker than the intervening, less-porous diatomaceous muds. 


\section{PRINCIPAL SEDIMENT COMPONENTS}

The principal biogenic components of the sediment samples studied are diatom frustules. These occur in both concentrated diatom ooze layers or laminae and are also ubiquitously associated with silt and clay in the dominant diatomaceous mud sediment. Benthic foraminifers are also relatively common but more variable in abundance and are sometimes preserved only as molds due to selective carbonate dissolution (Kearsley in Patience et al., this volume). Benthic foraminifers are most abundant in bioturbated sediments and progressively less abundant with increasing preservation of lamination. Planktonic foraminifers, radiolarians, and coccoliths are only rarely observed. Small qualities of finely disseminated calcium carbonate are often present, and dolomite occurs typically as rhombs. The terrigenous fraction is dominated by clay (smectite, illite, and chlorite; see Clayton and Kemp, this volume) and, predominantly, feldspathic silt. The dominant arrangement of sediment types is variably spaced, thin $(0.1$ to $10 \mathrm{~mm}$ ) diatom ooze laminae intercalated with diatomaceous mud or silty mud (Pl. 1).

\section{ASSOCIATION OF SEDIMENT COMPONENTS}

Substantial proportions of the diatomaceous muds consist of apparently random or haphazard arrangements of intact or fragmentary diatom frustules. However, several distinctive fabric elements are present. The origins of these elements (suggested below) are based on descriptions from the literature, but one may acknowledge that studies of fecal pellets, for example, are limited and have concentrated on copepod pellets (e.g., Honjo and Roman, 1978), with little data about other types (Bruland and Silver, 1981), and other origins than those suggested below may be involved. It is similarly acknowledged that "Marine Snow" may be responsible for significant sediment flux (e.g., Asper, 1987). However, these aggregates are highly labile and have little preservation potential (Lampitt, 1985) and are thus unlikely to be recognized as such in the sediment record.

\section{Pellets Containing Fragmental Skeletal Material}

Pellets made up of mainly broken and compacted diatom frustules are relatively common. These occur as a variable, sometimes major, component of diatomaceous muds and in diatom ooze laminae. These pellets are easily identifiable in BSE images ( $\mathrm{Pl} .2$ ) because they are substantially brighter (due to lower porosity) than the surrounding mud or ooze. Hence, the extent of pelletization of individual areas is readily quantifiable. Individual pellets are circular to oval in cross section, with the shortest diameters commonly ranging between 60 to $180 \mu \mathrm{m}$ and the longest diameters up to $300 \mu \mathrm{m}$. All centric and pennate diatoms within the pellets are present as broken fragments, except for diatom resting spores having a diameter of less than $10 \mu \mathrm{m}$ and for very rare pellets containing coccoliths. The internal structure of some pellets displays a well-developed concentric compactional fabric (PI. 2, Fig. 4), presumably formed within the gut of the herbivorous zooplankton. An intriguing feature of the internal contents of the pellets is the presence of much very fine opaline material (such as diatom setae), which is only rarely observed in the sediment matrix. This suggests differential silica dissolution, with very fine material being preserved within the compacted pellets and preferentially dissolved in the more open framework of the matrix. Alternatively, the presence of a surface membrane (Schrader, 1971) may also have prevented dissolution of fine siliceous material from pellets during settling in the water column.

The size range of these pellets, together with the fragmentary nature of the contained diatom frustules, compares best with descriptions of copepod fecal pellets (Honjo and Roman, 1978). Fragmental skeletal material in similar form has been recorded from near-surface sediments from the Peruvian upwelling zone (Reimers, 1982; Krissek and Scheidegger, 1983).

The distribution of copepod pellets is highly variable. In the diatomaceous mud intervals in between diatom ooze laminae, the concentration of pellets varies from $0 \%$ to more than $50 \%$. Within some thin diatomaceous mud intervals a "distribution grading" of fecal pellets is evident, with the percentage of pellets in the sediment decreasing upward.

\section{Aggregates Containing Intact Skeletal Material}

Aggregates contain predominantly intact skeletal material are locally common and generally occur in groups along the same horizon or, more rarely, are isolated. They are up to 3 $\mathrm{mm}$ long in section and up to $0.5 \mathrm{~mm}$ thick (Pl. 2). Smaller fragmental pieces having the same content and fabric are often associated with larger aggregates. Although mainly ovoid in section, in some cases, these aggregates have uneven edges that together with the wide size range suggest break up of larger aggregates. They contain a range of intact diatom types, including both centric and pennate forms and resting spores.

The maximum dimensions, wide size range, and intact skeletal content of the aggregates have affinities with descriptions of anchoveta fecal pellets described from the modern Peruvian coastal upwelling zone (Staresnic et al., 1983). In-situ observations by these authors indicate the presence of long $(>10 \mathrm{~mm})$ cylindrical strings, although mainly fragments were recovered from sediment trap samples. These observations are consistent with the wide size range of the aggregates observed here and suggest that most of the larger strings described by Staresnic et al. (1983) are fragmented during settling. Some of these fragments may possibly represent "rip-up clasts"' that have been eroded by current action from diatom ooze horizons. This is, however, unlikely as there would be little cohesion in such layers (containing intact diatoms) and, hence, little potential for transport en masse.

\section{Terrigenous Sediment Aggregates and Minor Bioturbation Structures}

Aggregates or concentrations of terrigenous sediment (silt and clay) are often associated with zones of minor bioturbation (evidenced by slight disruption of laminae) (Pl. 3). Some of these aggregates are obviously associated with redistribution of material between layers or laminae that result from burrowing. Other aggregates occur where there is no (other) general evidence for bioturbation. These oval-shaped structures generally fall in two size groups: one is 30 to $80 \mu \mathrm{m}$ in horizontal dimension by 25 to $50 \mu \mathrm{m}$ in vertical dimension; the other is 130 to $200 \mu \mathrm{m}$ in horizontal dimension by 50 to $130 \mu$ in vertical dimension. In some cases, the silt and clay within these structures is significantly more concentrated and/or compacted than it is in adjacent layers of terrigenous sediment (Pl. 3, Fig. 3). In addition, more circular and/or irregular shaped structures are obviously related to redistribution of material between layers (PI. 3, Fig. 1).

These structures may originate from a number of different actions of benthic organisms. Translation within the sediment with a component or vertical motion could produce the redistribution of material between layers. Sediment redistribution could also be produced by ingestion of sediment, with subsequent production of fecal pellets or tubes. The latter mechanism could also produce the concentration/compaction of the terrigenous sediment component observed. The wide range of size and type of structure observed suggests that probably more than one species is involved and that all of the above mechanisms might be taking place. What is certain, 


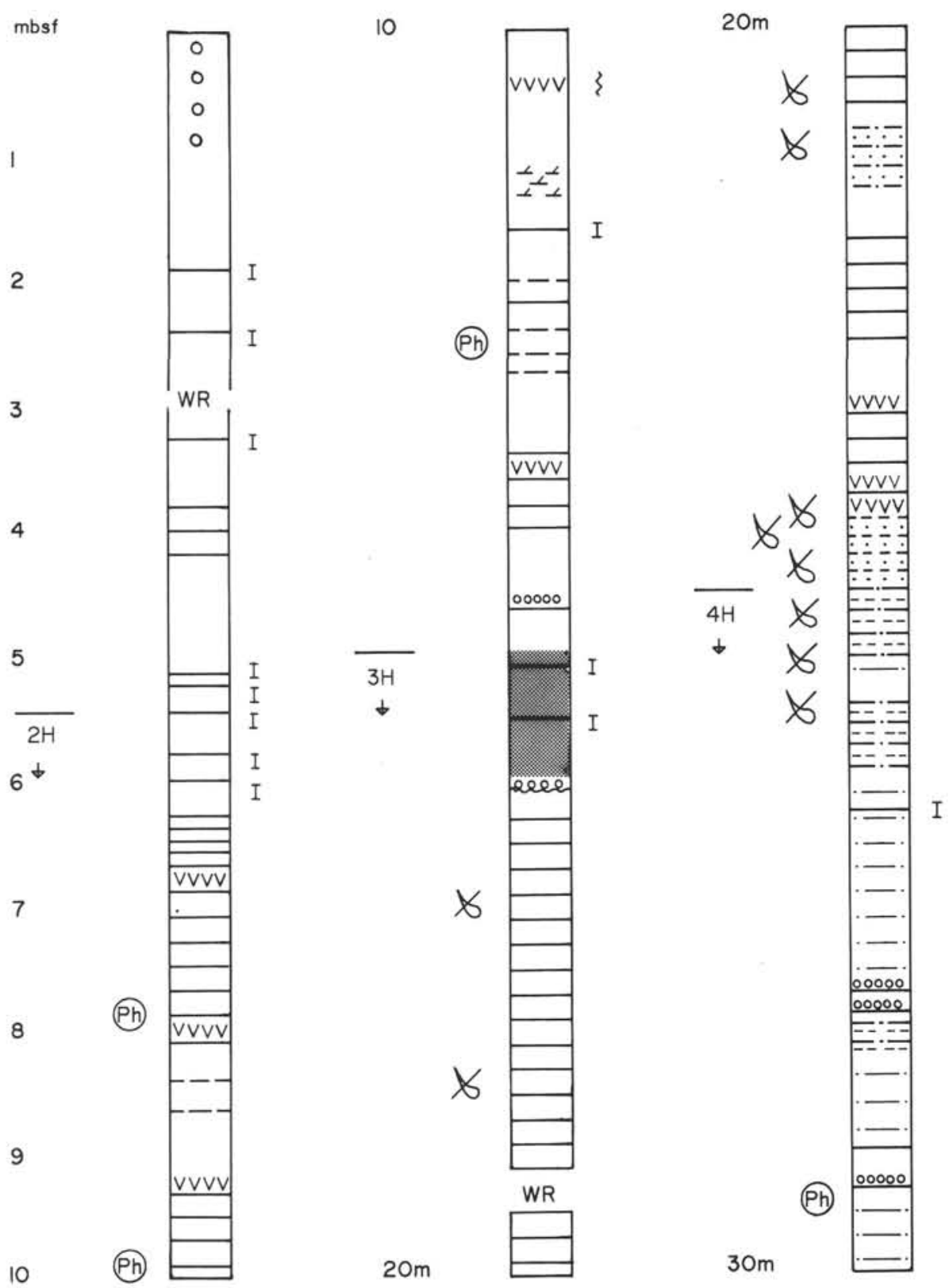

Figure 2. Sedimentological $\log$ of the Quaternary sequence of Hole $680 \mathrm{~B}$ showing lamina spacing and alternation between laminated and bioturbated intervals.

however, is that what bioturbation exists, is highly restricted, implying a very low concentration of dissolved oxygen.

To select the most likely processes for causing the disruption observed, one must consider previous studies of benthos of Peru and analogous settings. Within the oxygen-minimum zone off Peru, Frankenberg and Menzies (1968) recorded a relative abundance of polychaetes. Off California, Mullins et al. (1985) recorded a peak abundance of polychaetes within the core of the oxygen-minimum zone. Meiofaunal nematodes have also been recorded from similar environments (Rowe, 1981). From the range of probable burrowing mechanisms and sizes described above, both polychaetes and nematodes were probably responsible for the limited sediment disruption observed.

All the structures described above occur in sediments in which lamination is mainly macroscopically preserved. By using this criterion, the sediments may be described as anaer- obic (Savdra et al., 1984). Microscopically however, vertical and lateral variation clearly exists in the extent of burrowing, so that some relatively bioturbated layers could be described as dysaerobic (Pls. 3 and 4) (or "microscopically dysaerobic"?) This suggests variation in oxygen levels to allow for periodic minor benthic activity. Intriguingly, none of the laminated samples examined was completely devoid of the "bioturbational" structures observed above throughout the sample area $(2 \times 2 \mathrm{~cm})$.

\section{LAMINATION STYLE}

The following section details the nature of the lamination encountered in the upwelling sediments and, in particular, the results of SEM studies of lamina-fine structure. Laminations may be classified on the basis of several distinct fundamental parameters, including composition, spacing, thickness, and internal structure. 


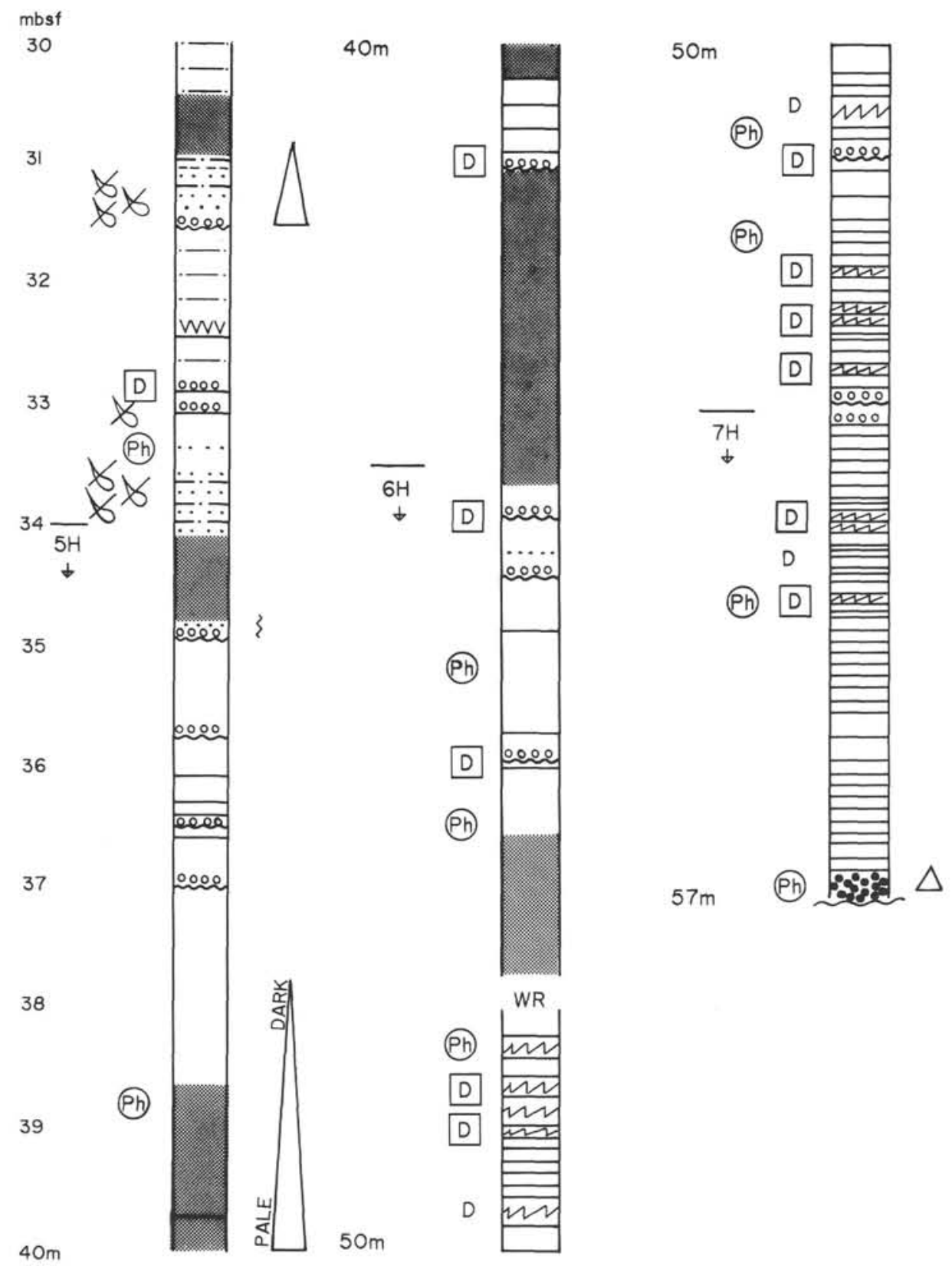

Figure 2 (continued).

The ultimate reason for studying laminations must be to relate them genetically to paleoceanographic events. However, this must await correlation of depositional events with water column processes. For the purposes of classification of laminae in these ancient Peru-margin sediments, I have adopted a descriptive, rather than genetic, approach.

\section{Composition of Lamina}

Laminations may be classified on a compositional basis as biogenic, terrigenous, mixed (biogenic and terrigenous), or chemical (Table 1).

The most abundant biogenic laminations are made up of diatom frustules. Rare examples of coccolith ooze were encountered, as well as exceptionally foraminifer-rich lamina- tions. Diatom ooze and mixed (biogenic-terrigenous) laminations are discussed in detail below.

Laminations containing terrigenous sediment concentrations (relative to the usually diatomaceous mud) occur with a variety of thicknesses ranging from less than $1 \mathrm{~mm}$ to transitional to centimeter- or decimeter-thick beds. These laminae and beds are relatively dark and generally contain some admixed diatom debris. Terrigenous laminae occur separately or as a component of the "varve-type" lamina facies association (see below), where both discrete mud and, more rarely, silt laminae of up to $2 \mathrm{~mm}$ thick occur (Pl. 4).

Chemical laminae of pale yellow, friable phosphate are locally common (see Garrison et al., this volume). Diagenetic dolomite laminae occur more commonly with increasing depth and often seem to follow foraminifer-rich layers. Dolomitic 
DIATOMACEOUS MUD
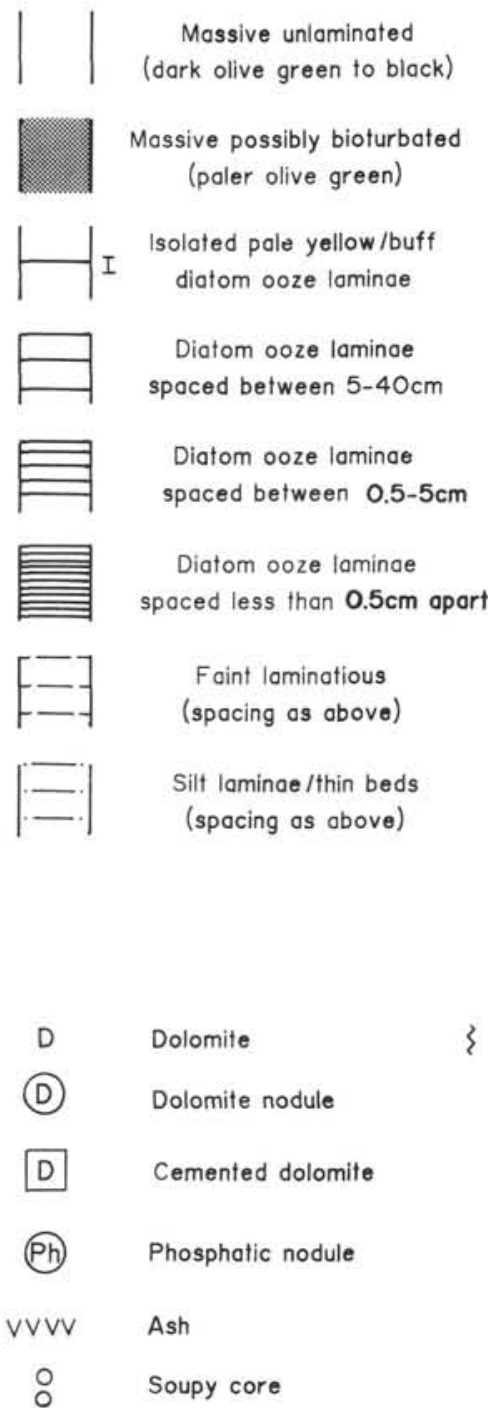

Figure 2 (continued).

layers are particularly common in lithologic Unit IB of Site 680 (Pl. 1 and Fig. 2).

\section{Spacing of Lamina}

Spacing of the most common lamina compositional type, diatom ooze, ranges from submillimeter to decimeter size. Diatom-ooze lamina spacing in the Quaternary sequences of Holes $680 \mathrm{~B}$ and $686 \mathrm{~B}$ is shown in Figures 2 and 3. Greater spacing between laminae is probably not related to bioturbation unless indicated, and is thus a primary depositional effect.

\section{Internal Structure of Diatom Ooze Laminae}

The internal structure of diatom-ooze laminae is varied and often complex. Diatom ooze laminae may be broadly divided into "pure-ooze" laminae and "mixed-ooze/terrigenous sediment" laminae, which are composed mainly of diatom ooze, but have internal microlayers of terrigenous sediment (PI. 4 through 6).

\section{OTHER LITHOLOGIES}

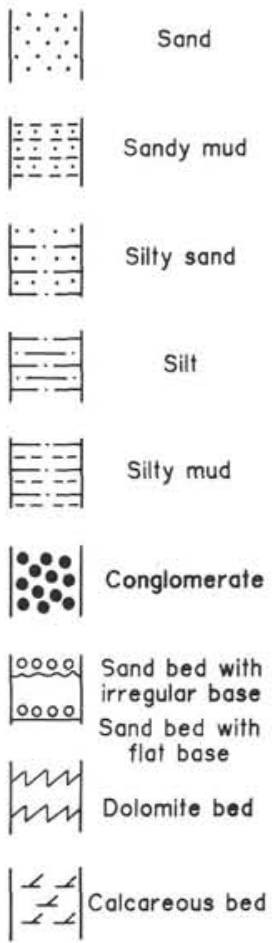

Slight/moderate/severe biofurbation

Shell debris

$\Omega \quad$ Slumping

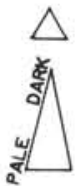

Graded bed

Colour grodation

\section{"Pure-Ooze" Laminae}

The simplest form of diatom-ooze laminae (simple-ooze laminae) is made up of thin 30 - to $1000-\mu \mathrm{m}$ layers of intact or pelleted, low-diversity, sometimes monospecific, diatom frustules (Pl. 5). These laminae occur both as isolated within diatomaceous mud and as component microlayers of more complex ooze laminae. Composite pure-ooze laminae vary considerably in thickness, ranging up to more than $1 \mathrm{~cm}(\mathrm{Pl}$. 5). These laminae consist of a number of distinct layers that may be delineated by such factors as differing diatom species, layers of resting spores, the alternation of intact and broken or pelleted diatoms, or increases or decreases in abundances of individual components. These integral microlayers can commonly be traced throughout individual composite laminae. Both pure- and composite-ooze laminae may have minor admixtures of terrigenous sediment, but this is disseminated throughout, rather than concentrated in layers as in the mixed-ooze/terrigenous laminae (below). 


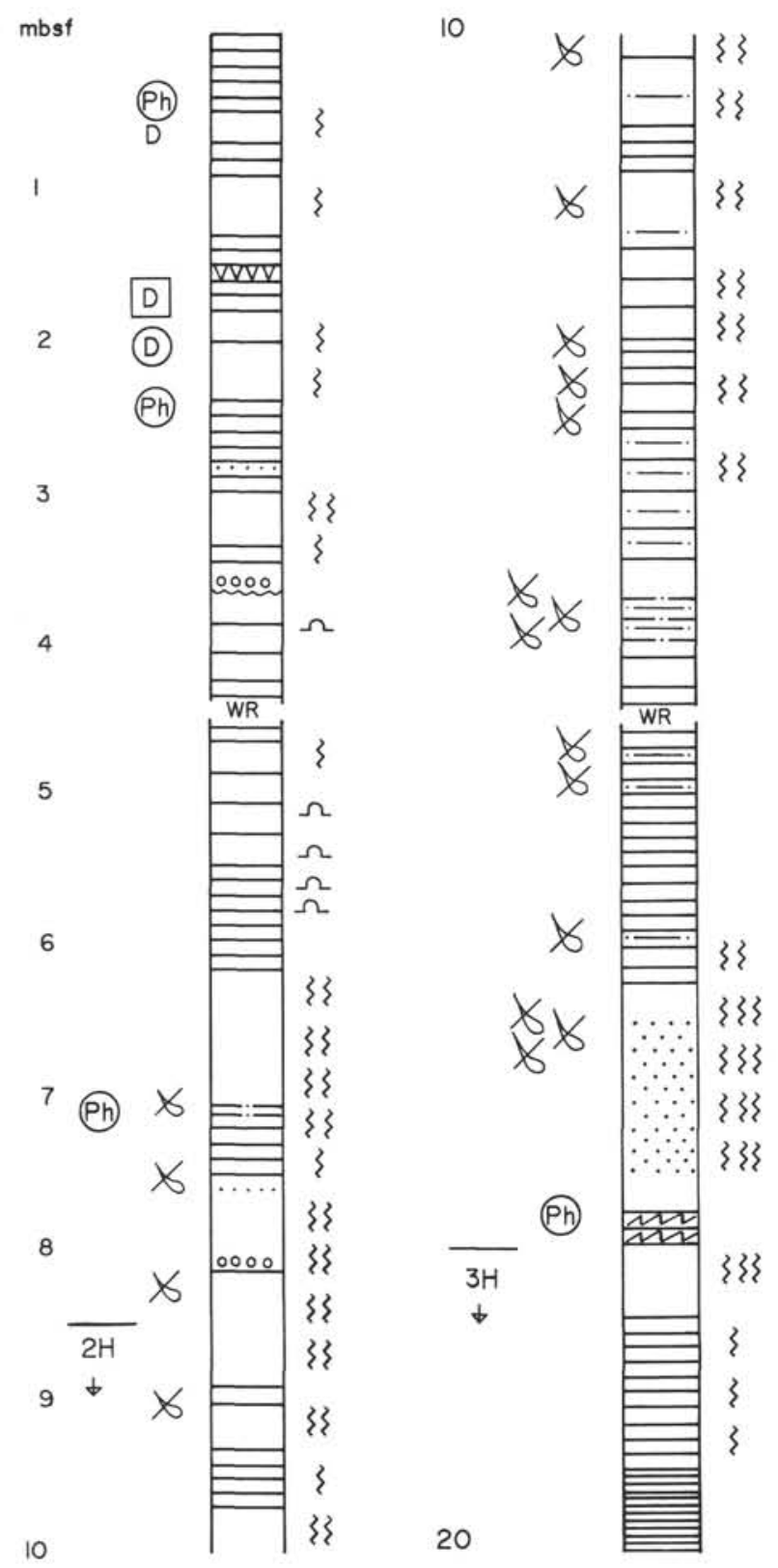

20

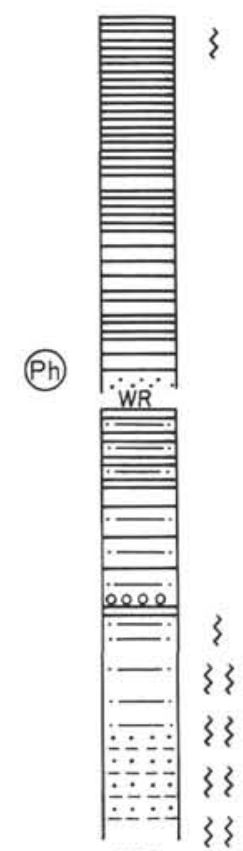

3

WR

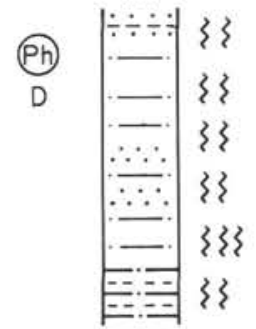

Figure 3. Sedimentological log of the top of Hole 686B. Key as for Figure 2.

\section{Mixed-Ooze/Terrigenous Laminae}

Mixed-ooze/terrigenous laminae range from $0.5 \mathrm{~mm}$ to several centimeters thick and superficially resemble composite-ooze laminae. BSE imagery, however, indicates the presence of multiple internal microlayers comprising, wholly or in part, terrigenous silt ( $\mathrm{Pl}$. 6). These range between 10 and 100 $\mu \mathrm{m}$ thick. They may also contain diatomaceous material of larger grain size than the interlaminated diatom-ooze layers (Pl. 6, Fig. 3). The terrigenous sediment microlayers sometimes display discordant relationships with adjacent layers of sediment (PI. 6, Figs. 1, 2).

\section{Origins and Depositional Mechanisms of Diatom-Ooze Laminae}

The simple pure-ooze laminae (made up of intact frustules of few or one species, resting spores, and/or chaetoceros bristles) are most likely fall out from individual seasonal plankton blooms. The relatively intact nature of the frustules suggests individual transport through the water column, although transport in anchovy fecal pellets that have subsequently disintegrated cannot be ruled out. Some simple pureooze layers are composed of probable copepod fecal pellets, suggesting some degree of pelletization contributing to downward flux.

Composite pure-ooze laminae are internally variable and show evidence of a series of distinct sequential components that suggest discrete depositional events and/or a progressively changing fall out. Thus, depositional mechanisms include both independent frustules settling and pelletization. A component of reworking of diatomaceous material or deposition from density currents cannot be ruled out in some cases. The internal structure of each composite lamina must be 
Table 1. Classification of laminations.

\begin{tabular}{|c|c|c|c|c|c|c|c|c|}
\hline \multicolumn{3}{|c|}{ LAMINA TYPE } & COMPOSITION & THICKNESS & SPACING & REGULARITY & FREQUENCY OF OCCURENCE & ORIGIN \\
\hline \multirow{3}{*}{ Biogenic } & \multirow{2}{*}{$\begin{array}{c}\text { Diatom } \\
\text { ooze }\end{array}$} & $\begin{array}{l}\text { Simple } \\
\text { ooze }\end{array}$ & $\begin{array}{l}\text { Mainly intoct diatoms } \\
\text { resting spores /bristles } \\
\text { monospecific or low } \\
\text { diversity ossemblages }\end{array}$ & $30-1000 \mu$ & $\begin{array}{l}\text { Commonly } \\
\text { sub-milli } \\
\text {-meter }\end{array}$ & $\begin{array}{l}\text { May be very regular } \\
\text { seporated by similar } \\
\text { thicknesses of } \\
\text { terrigenous sediment }\end{array}$ & $\begin{array}{l}\text { Locally dominant in high } \\
\text { sedimentation rate } \\
\text { intervals }\end{array}$ & $\begin{array}{l}\text { Fall out from } \\
\text { individual bloom } \\
\text { events }\end{array}$ \\
\hline & & $\begin{array}{c}\text { Composite } \\
\text { ooze }\end{array}$ & $\begin{array}{l}\text { Distinct layers defined } \\
\text { by differences in } \\
\text { diatom species/ } \\
\text { extent of frogmentotion } \\
\text { of frustules }\end{array}$ & $\begin{array}{l}\text { variable } \\
\text { to over } \\
\text { 10 mm }\end{array}$ & varioble & $\begin{array}{l}\text { Moinly irregular, } \\
\text { moy occur in } \\
\text { bundles }\end{array}$ & $\begin{array}{l}\text { Dominant lamina type in } \\
\text { late Neogene sequences }\end{array}$ & $\begin{array}{c}\text { Foll out from } \\
\text { sequentiol bloom } \\
\text { events without intervening } \\
\text { terrigenous sediment } \\
\text { deposition / } \\
\text { some current reworking }\end{array}$ \\
\hline & \multicolumn{2}{|c|}{ Coccolith ooze } & Coccoliths & $\begin{array}{l}\text { up to } \\
1000 \mu\end{array}$ & voriable & - & Very rare & $\begin{array}{l}\text { Fall out from } \\
\text { bloom events }\end{array}$ \\
\hline \multicolumn{3}{|c|}{$\begin{array}{l}\text { Mixed diatom ooze } \\
\text { terrigenous sediment }\end{array}$} & $\begin{array}{l}\text { Loyers of variably } \\
\text { intact or frogmental } \\
\text { diatorns alternating } \\
\text { with thinner } 10-100 \mu \\
\text { microlayers of } \\
\text { terrigenous sediment }\end{array}$ & $\begin{array}{l}500 \mu \text { to } \\
\text { several cm }\end{array}$ & $\begin{array}{l}\text { variable } \\
\text { may be } \\
\text { closely } \\
\text { spaced }\end{array}$ & Moy be regular & $\begin{array}{l}\text { ? Common (These con only } \\
\text { be identified using SEM) }\end{array}$ & $\begin{array}{l}\text { Suspension fall out I } \\
\text { tractional deposition } \\
\text { from low density } \\
\text { furbidity ond /or } \\
\text { botfom currents } \\
\text { containing } \\
\text { resuspended } \\
\text { sediment }\end{array}$ \\
\hline \multicolumn{3}{|c|}{ Terrigenous sediment } & $\begin{array}{l}\text { Silt/sand with } \\
\text { subordinate clay }\end{array}$ & $\begin{array}{l}50 \mu \text { to } \\
\text { decimeter- } \\
\text { beds }\end{array}$ & variable & $\begin{array}{l}\text { Mainly irregular } \\
\text { except in some } \\
\text { organic- } \\
\text { poor intervals }\end{array}$ & $\begin{array}{l}\text { Rare in dark, organic- } \\
\text { rich intervals, common } \\
\text { in paler organic-poor } \\
\text { intervals }\end{array}$ & $\begin{array}{l}\text { Deposition from low- } \\
\text { medium density } \\
\text { turbidity currents } \\
\text { or shelf-bottom } \\
\text { currents }\end{array}$ \\
\hline \multicolumn{3}{|c|}{ Chemical } & Dolomite, phosphate & $\begin{array}{l}500 \mu- \\
\text { several cm }\end{array}$ & variable & Irregular & $\begin{array}{l}\text { Moinly low: obundonce of } \\
\text { dolomitic loyers increases } \\
\text { with depth (Figure 2) }\end{array}$ & $\begin{array}{l}\text { Diagenetic (see } \\
\text { Garrison ef ol., this } \\
\text { volume) }\end{array}$ \\
\hline
\end{tabular}

examined in detail. While some such laminae, or at least parts of them, might represent the record of one diatom bloom event, others probably record sequential blooms without intervening deposition of terrigenous sediment.

\section{Mixed-Ooze/Terrigenous Laminae}

The alternation of microlayers of terrigenous silt with diatomooze layers might represent a "micro-" varve-type lamination. However, the microlayers are probably too thin to support this mode of origin. In addition, the discordant contacts displayed (PI. 6) are difficult to account for with this model. The association of some larger diatom debris with the silt layers might suggest some element of size sorting that is associated with their formation. In their overall appearance, the microlayers bear some resemblance to the parallel lamination found in the deposits of low-density turbidity currents, for which sorting processes in the viscous sublayer are held responsible (Hesse and Chough, 1980; Stow and Bowen, 1980). Alternatively, the discordant relationships observed might suggest that these microlayers may constitute some form of low-angle ripple bedform. Whatever the precise origins of these enigmatic layers, it seems most likely that they have formed in response to some current activity and are not the result of settling from the surface layers. Clearly, this mode of origin has implications for the fate of organic material.

\section{LAMINA FACIES ASSOCIATIONS}

The diatom-ooze lamina described above tend to occur in associations. For the purposes of this study, these associations or types were split into two broad categories: spaced lamination and varve-type lamination. The occurrence and distribution of these two lamina facies associations are shown in Figures 2 and 3.

\section{Spaced Lamination Facies Association}

Most of the diatom-ooze laminated intervals have a lamina spacing greater than $0.5 \mathrm{~cm}$ (Figs. 2, 3) (although thin groups of laminae may have closer spacing). The overall spacing of laminae within these intervals is irregular, commonly with bundles of more closely spaced laminae with gaps. This irregularly spaced lamination is typical of the Quaternary upwelling sequences recovered during Leg 112. The individual laminae occurring in these intervals are generally the "composite pure-ooze" or "mixed-ooze/terrigenous" types. Isolated examples of the "simple pure-ooze". lamina type are relatively rare.

\section{Varve-Type Lamination Facies Association}

The varve-type lamina facies association is characterized by close and regular spacing of laminae (generally $<2 \mathrm{~mm}$ ) and by the thickness of the ooze laminae, which are of the same order of thickness as the intervening terrigenous sediment. Individual laminae are generally of the simple pure-ooze type or else relatively thin examples of the composite pure-ooze type. Great variability occurs in the terrigenous sediment between the ooze layers, which may be composed of one or a combination of diatomaceous mud, diatom-poor mud, silty mud, or silt. The stacking order of these components varies at different intervals, and the resolution of this made possible by BSEI is great (e.g., Pl. 4). This lamination style is called "varve-type" because of its resemblance to lamination described from the continental margin off California and the Gulf of California (e.g., Anderson et al., 1987).

\section{Significance of Lamination Style}

The scale and internal microstructure of the varve-type lamina facies association suggest that it forms in response to some regularly recurrent (possibly annual or seasonal) variation in type or rate of sediment flux. Clearly, there must be some regular terrigenous and biogenic influx. The scale of alternation between terrigenous and biogenic influx suggests that the influx of at least one, if not both components, must vary seasonally. In examples of varve-type lamination studied 
off California, the terrigenous influx is related to seasonal rains, which vary in time of occurrence from summer in the Gulf of California (Donegan and Schrader, 1982) or winter in the California Borderland basins (Anderson et al., 1987; Soutar and Crill, 1977). By analogy, this suggests that the varve-type lamination encountered in the Peru forearc basins may reflect some similar wet season-related runoff. Significantly, the sequences cored during Leg 112, in which varvetype laminations were encountered, are characterized by higher sedimentation rates (at least $160 \mathrm{~m} / \mathrm{m}$.y. at Site 686 ) than those that lack varve-type lamination (e.g., Site 680, $20-32 \mathrm{~m} / \mathrm{m} . \mathrm{y}$.$) .$

The spaced laminations may record episodic blooms or rare megablooms, or in the case of the mixed-ooze/terrigenous lamina type, erosion and reworking of diatom ooze and mud. Lower sedimentation rates may be more characteristic of this facies (see above), although spaced lamination also occurs at Site 686. Rare bundles of ooze laminae within this facies may represent a sporadic record of seasonal events.

\section{Regional and Stratigraphic Distribution of Lamina Facies}

Most of the lamination encountered in the Peru forearc basins is of the spaced lamination style. The occurrence of significant thicknesses of varve-type lamination is limited to parts of the Quaternary of Site 686 and the Pliocene-Miocene sequence of Site 688 . The rarity of varve-type lamination elsewhere may relate to lower bulk sedimentation rates and/or the lack of regular wet seasons, giving rise to terrigenous influx. Significantly, the youngest varve-type laminations at Site 686 are about 100 k.y., suggesting that wet seasons last occurred along the Peruvian coast at this time (no wet season currently occurs along the coastal strip, except for brief, sporadic rain during El Niño events).

\section{CONCLUSIONS}

Detailed study of Pliocene-Quaternary laminated sediments from the Peruvian continental margin reveals great variation in composition, spacing, and thickness of laminae.

Diatom-ooze laminations, which represent fall out from diatom blooms, range in type from simple layers consisting of one or a few species to composite laminae comprising several internal microlayers. Some diatom-ooze laminae that contain microlayers of terrigenous sediment were probably deposited or redeposited by bottom currents.

A regular varve-type lamination that suggests seasonal variation in biogenic and/or terrigenous influx occurs in stratigraphically and geographically restricted intervals in the Quaternary and Pliocene-Miocene, which are characterized by relatively high sedimentation rates.

A wide range of pelletal and aggregate structures within the sediment are variously interpreted as fecal pellets formed by plankton and nekton within the water column and as the product of sediment disruption and ingestion by benthos. Significantly, even the well-laminated sediments examined show some SEM-scale evidence for benthic activity, suggesting that oxygen levels periodically rose sufficiently to allow inhibited benthic activity.

BSEI of resin-impregnated, unconsolidated sediments is a viable technique for resolving and studying sedimentary fabrics. In conjunction with secondary electron imagery, this technique has great potential for high-resolution paleoceanographic, paleoclimatological, and sedimentological process studies.

\section{ACKNOWLEDGMENTS}

My participation in Leg 112 was funded by NERC, and SEM time was funded by the NERC ODP Special Topic. I thank A. Kearsley of
Oxford Polytechnic for help with electron microscopy and for sample preparation.

\section{REFERENCES}

Anderson, R. Y., Hemphill-Haly, E., and Gardner, J. V., 1987. Persistent late Pleistocene-Holocene Seasonal Upwelling and Varves off the coast of California. Quat. Res., 28:307-313.

Asper, V. L., 1987. Measuring the flux and sinking speed of marine snow aggregares. Deep-Sea Res., 34:1-17.

Baumgartner, T., Ferreira-Bartrina, V., Schrader, H., and Soutar, A., 1985. A 20-year varve record of siliceous phytoplankton variability in the central Gulf of California. Mar. Geol., 64:113129.

Bruland, K. W., and Silver, M. W., 1981. Sinking rates of fecal pellets from gelatinous zooplankton (Salps, Pteropods, Doliolids). Mar. Biol., 63:295-300.

Calvert, S. E., 1966. Origin of diatom-rich, varved sediments from the Gulf of California. J. Geol., 74:546-565.

De Vries, T. J., and Schrader, H., 1981. Variation of upwelling/ oceanic conditions during the latest Pleistocene through Holocene off the central Peruvian coast: a diatom record. Mar. Micropaleontol., 6:157-167.

Donegan, D., and Schrader, H., 1982. Biogenic and abiogenic components of laminated hemipelagic sediments in the central Gulf of California. Mar. Geol., 48:215-237.

Drake, D. E., and Cacchione, D. A., 1985. Seasonal variation in sediment transport on the Russian River shelf, California. Cont. Shelf Res., 4:495-514.

Dunbar, R. B., and Berger, W. H., 1981. Fecal pellet flux to modern bottom sediment of the Santa Barbara Basin (California) based on sediment trapping. Geol. Soc. Am. Bull., 92:212-218.

Frankenberg, D., and Menzies, R. J., 1968. Some quantitative analysis of deep-sea benthos off Peru. Deep-Sea Res., 15:623-626.

Goldstein, J. I., Newbury, D. E., Echlin, P., Joy, D. C., Fiori, C., and Lifshin, E., 1981. Scanning Electron Microscopy and X-ray Microanalysis: New York (Plenum Press).

Hesse, R., and Chough, S. K., 1980. The north-west Atlantic midocean channel of the Labrador Sea: II. Deposition of parallel laminated levee-muds from the viscous sub-layer of low density turbidity currents. Sedimentology, 27:697-711.

Honjo, S., Roman, R. R., 1978. Marine copepod fecal pellets: production, preservation and sedimentation. J. Mar. Res., 38:45-57.

Krinsley, D. H., Pye, K., and Kearsley, A. T., 1983. Application of backscattered electron microscopy in shale petrology. Geol, Mag., 120:109-114.

Krissek, L. A., and Scheidegger, K. F., 1983. Environmental controls on sediment texture and composition in low oxygen zones off Peru and Oregon. In Suess, H., and Thiede, J. (Eds.) Coastal Upwelling: Its sediment record: New York (Plenum Press), NATO Conf. Ser. IV, Vol 10A, 163-180.

Lampitt, R. S., 1985. Evidence for the seasonal deposition of detritus to be deep-sea floor and its subsequent resuspension. Deep-Sea Res., 32:885-897.

Mullins, H. T., Thompson, J. B., McDougall, K., and Vercoutere, T. L., 1985. Oxygen-minimum zone edge effects: evidence from the central California coastal upwelling system. Geology, 13:491-494.

O'Sullivan, P. E., 1983. Annually laminated lake sediments and the study of Quaternary environmental changers a review. Quat. Sci. Rev., 1:245-313.

Pye, K., and Krinsley, D. H., 1984. Petrogrpahic examination of sedimentary rocks in the SEM using backscattered electron detectors. J. Sediment. Petrol., 54:877-888.

Reimers, C. E., 1982. Organic matter in anoxic sediments of central Peru: relations of porosity, microbial decomposition and deformation properties. Mar. Geol., 46:175-197.

Reimers, C. E., and Suess, E., 1983. Spatial and temporal patterns of organic matter accumulation on the Peru continental margin. In Thiede, J., and Suess, E. (Eds.), Coastal Upwelling: Its Sediment Record: New York (Plenum Press), NATO Conf. Ser. IV, Vol. 10B, 311-346.

Rowe, G. T., 1981. The benthic processes of coastal upwelling ecosystems. In Richards, F. A. (Ed.), Coastal Upwelling: Washington (Am Geophys. Union), Coastal and Estuarine Sci. 1, 464-471. 
Savrda, C. E., Bottjer, D. J., and Gorsline, D. S., 1984. Developments of a comprehensive oxygen-deficient marine biofacies model: evidence from Santa Monica, San Pedro and Santa Barbara Basins, California continental borderland. AAPG Bull., 9:11791192.

Schrader, H., 1971. Fecal pellets: role in sedimentation of pelagic diatoms. Science, 174:55-57.

Soutar, A., and Crill, P. A., 1977. Sedimentation and climatic patterns in the Santa Barbara Basin during the 19th and 20th centuries. Geol Soc Am. Bull., 88:1161-1172.

Staresnic, N., Farrington, J., Gagosian, R. B., Clifford, C. H., and Hulburt, E. M., 1983. Downward transport of particulate matter in the Peru coastal upwelling: role of anchoveta, Engraulis ringerns. In Suess, E., and Thiede, J. (Eds.), Coastal Upwelling: Its sediment record: New York (Plenum Press), NATO Conf. Ser. IV, Vol 10A, 225-240.
Stow, D.A.V., and Bowen, A. J., 1980. A physical model for the transport and sorting of fine-grained sediments by turbidity currents. Sedimentology, 27:31-46.

Suess, E., Kulm, L. D., and Killingley, J. S., 1986. Coastal upwelling and a history of organic-rich mudstone deposition off Peru. In Brooks, J., and Fleet, A. J. (Eds.), Marine Petroleum Source Rocks: London (Geol. Soc. [London]), Spec. Publ., 24:181-197.

Suess, E., von Huene, R., et al., 1988. Introduction, objectives, and principal results, Leg 112, Peru Continental Margin. In Suess, E., von Huene, R., et al., Proc. ODP., Init. Repts., 112: College Station, TX (Ocean Drilling Program),

Date of initial receipt: 28 December 1988

Date of acceptance: 23 August 1989

Ms 112B-135 


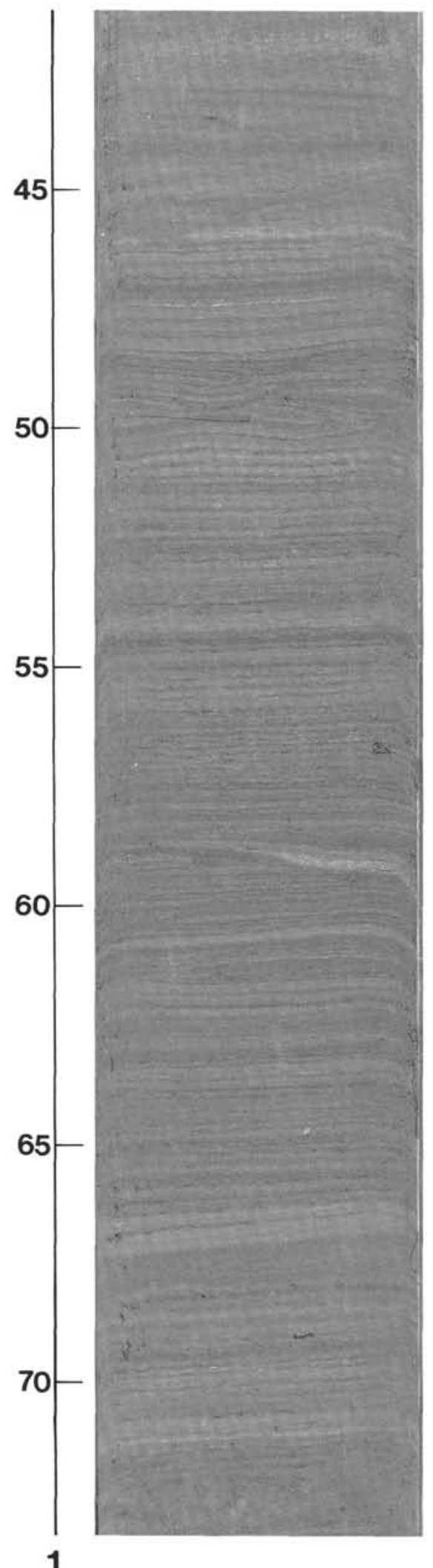
1

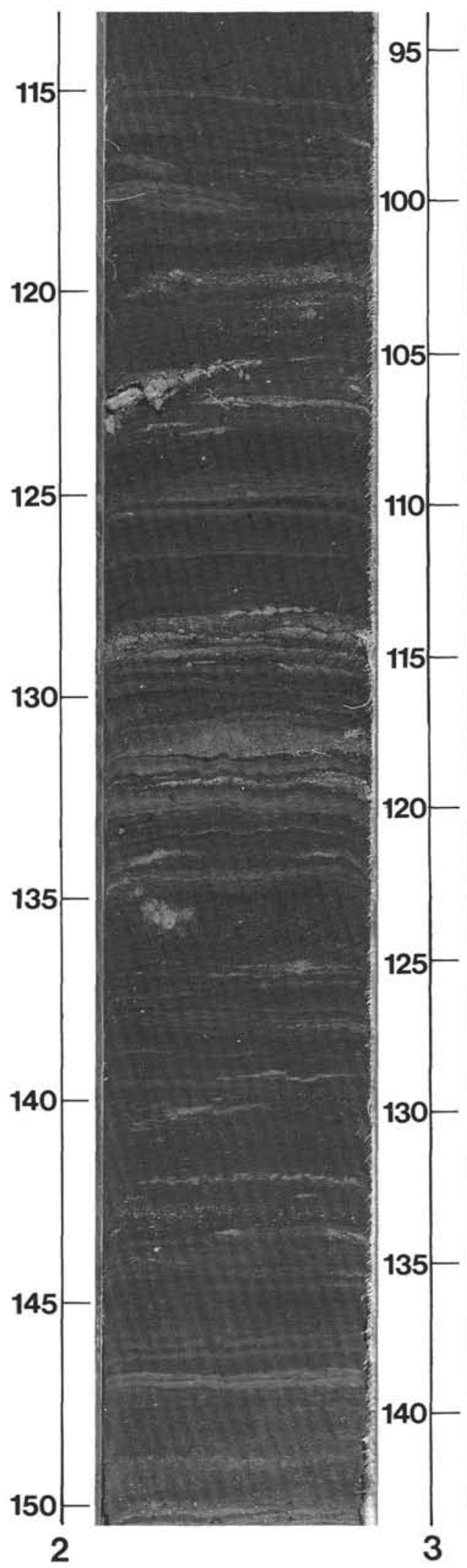

3

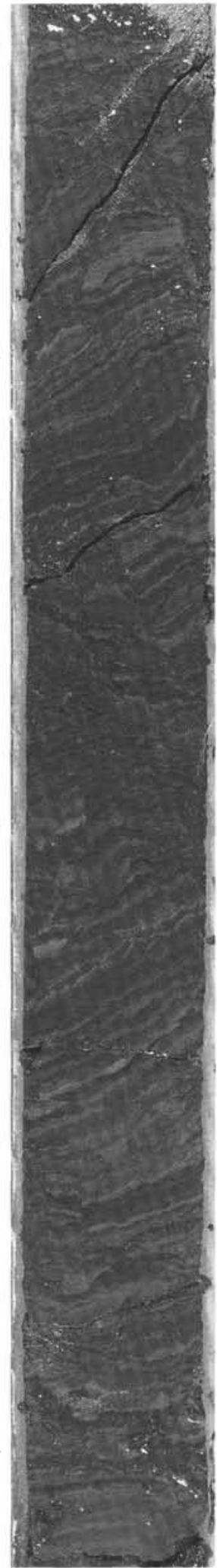

Plate 1. Examples of lamination from Leg 112 cores. 1. Varve-type lamina facies association in the Quaternary upwelling sediments of Site 686 (Sample 112-686B-3H-2, 42-73 cm). 2. Variably spaced composite and simple diatom-ooze laminae in spaced lamina facies association in lithologic Subunit IB of Site 680 . Some laminae are the locus of dolomite cementation (Sample 112-680B-6H-6, 113-150 cm). 3. Deformed laminated sequence from the Pliocene-Miocene of lithologic Subunit IIB of Site 688 (Sample 112-688E-6R-5, 94-143 cm). 


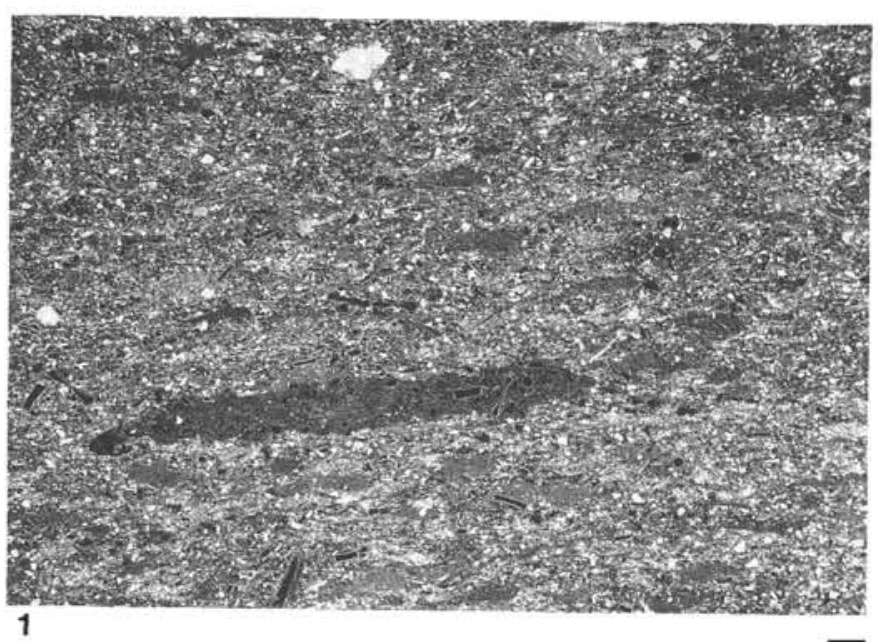

1
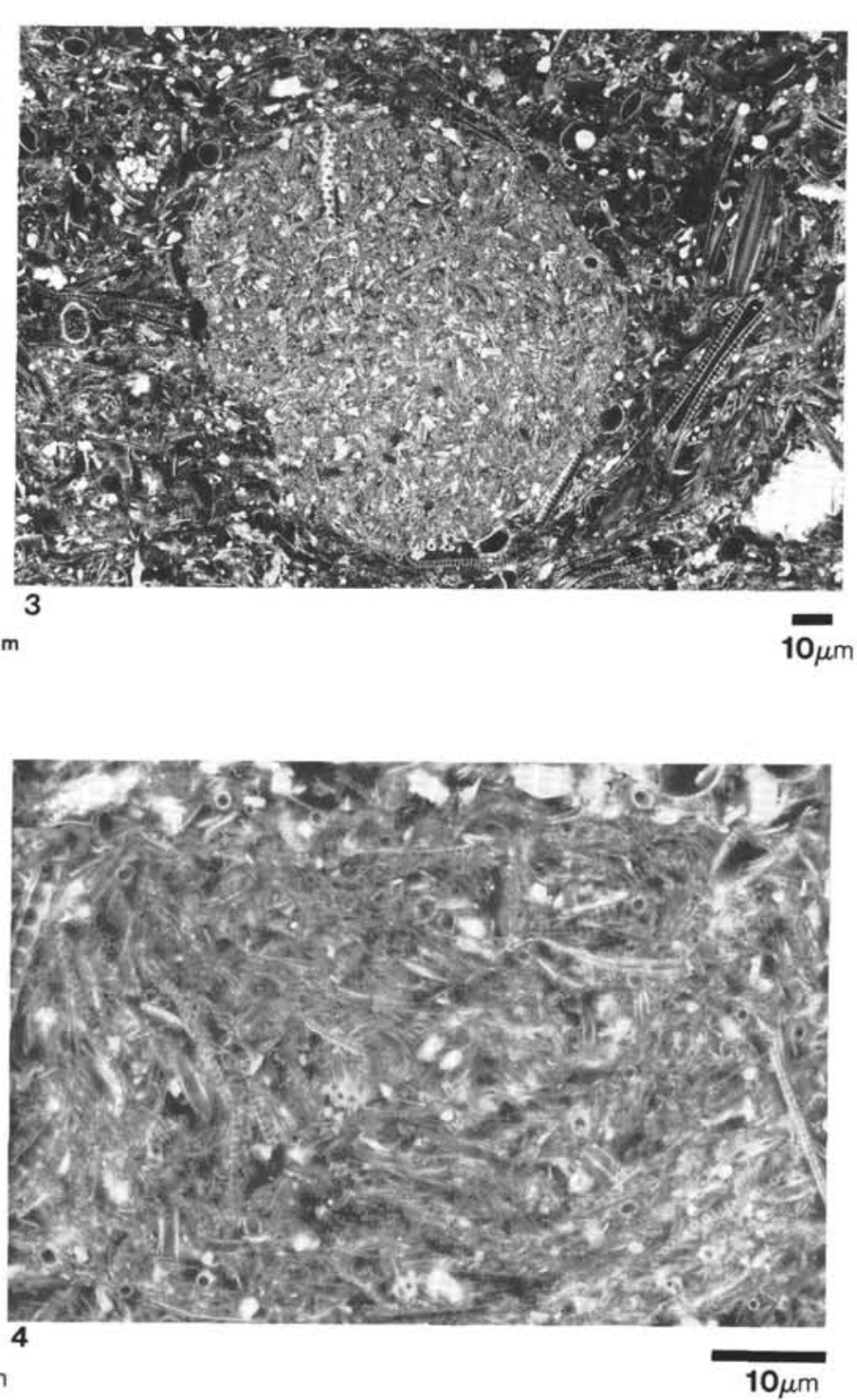

Plate 2. Back-scattered electron images showing planktonic fecal pellets. 1. General view of ?fragment of ?anchovy fecal pellet in diatomaceous silty mud. The paler, smaller pellets in the mud are probably copepod pellets. 2. Detail of Figure 1 showing intact and commonly articulated diatom frustules inside pellet. 3. Copepod fecal pellet containing compacted fragmental diatom debris. 4. Detail of internal fabric within a copepod in the surrounding diatomaceous mud, is preserved ind detail of very fine material, such as diatom setae. This very fine material, less common 


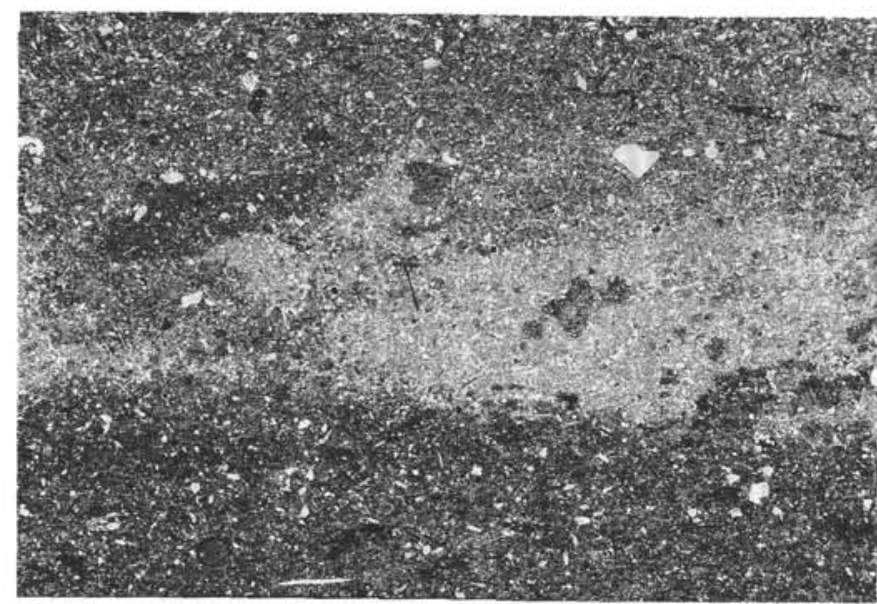

1
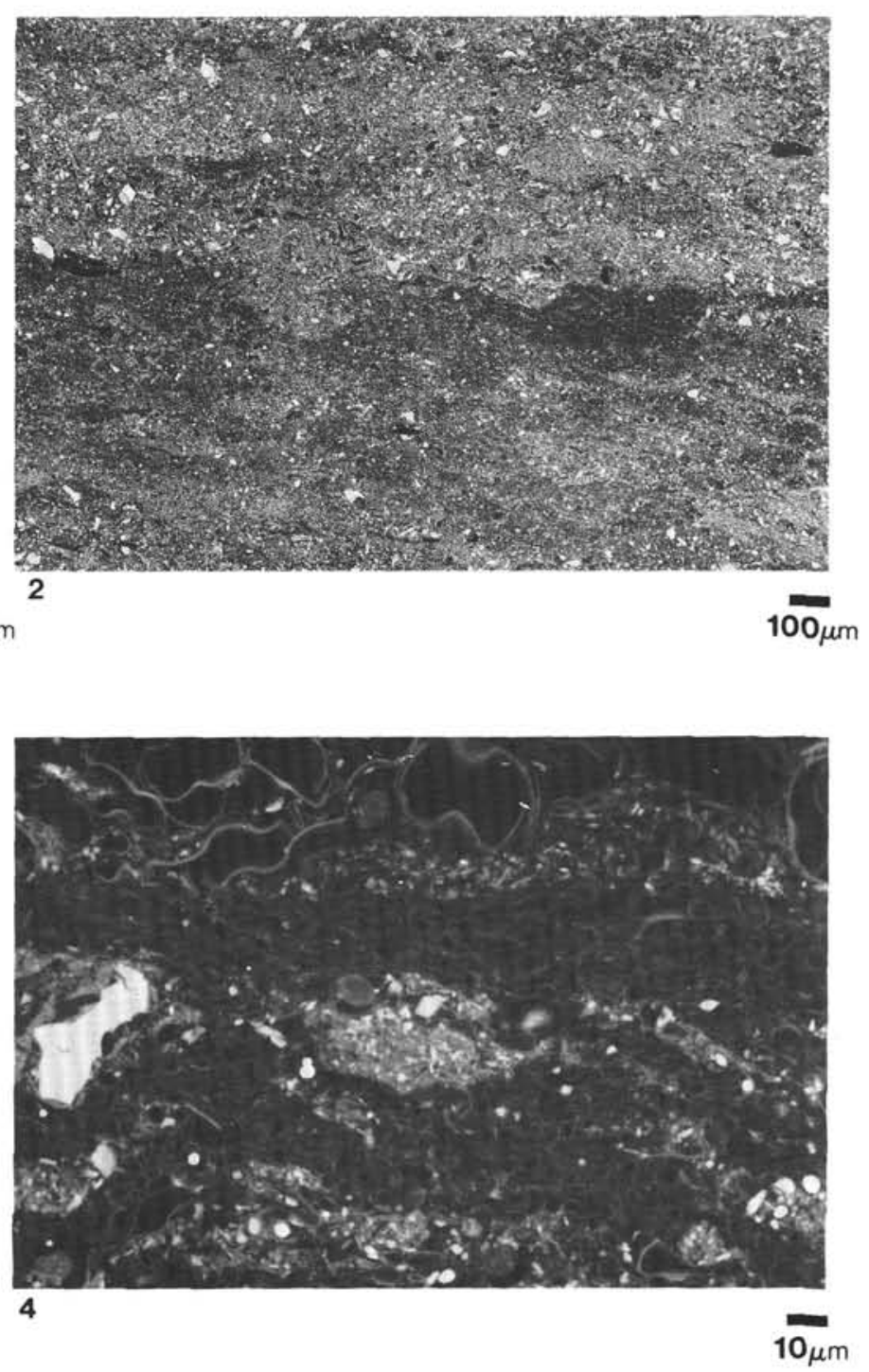

$100 \mu \mathrm{m}$

$100 \mu \mathrm{m}$

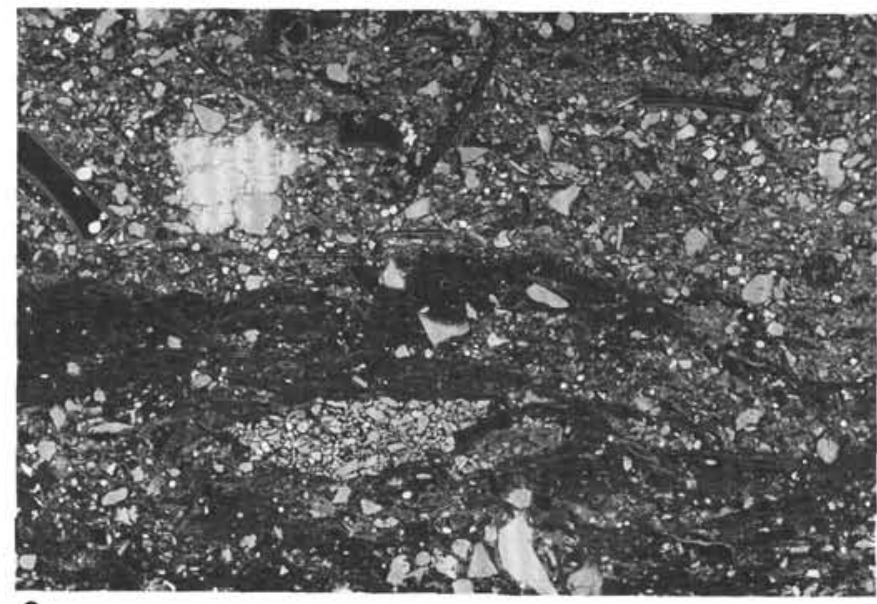

3

$100 \mu \mathrm{m}$

Plate 3. BSEI of terrigenous sediment aggregates and minor bioturbation structures. 1. Redistribution of material between a terrigenous silt layer and the enclosing diatomaceous mud. 2. Detail showing bioturbation of lamina $\mathrm{E}$ of Plate 4, which is transitional to complete homogenization of the sediment. Note the prominent discrete sediment aggregates/?burrow fills. 3. Sediment aggregate (lower center) in top of diatom-ooze layer. Terrigenous silt and clay are concentrated in the pellet relative to the overlying diatomaceous mud. This concentration may have occurred during sediment ingestion and subsequent excretion. 4. A much smaller terrigenous sediment aggregate within diatom ooze. 


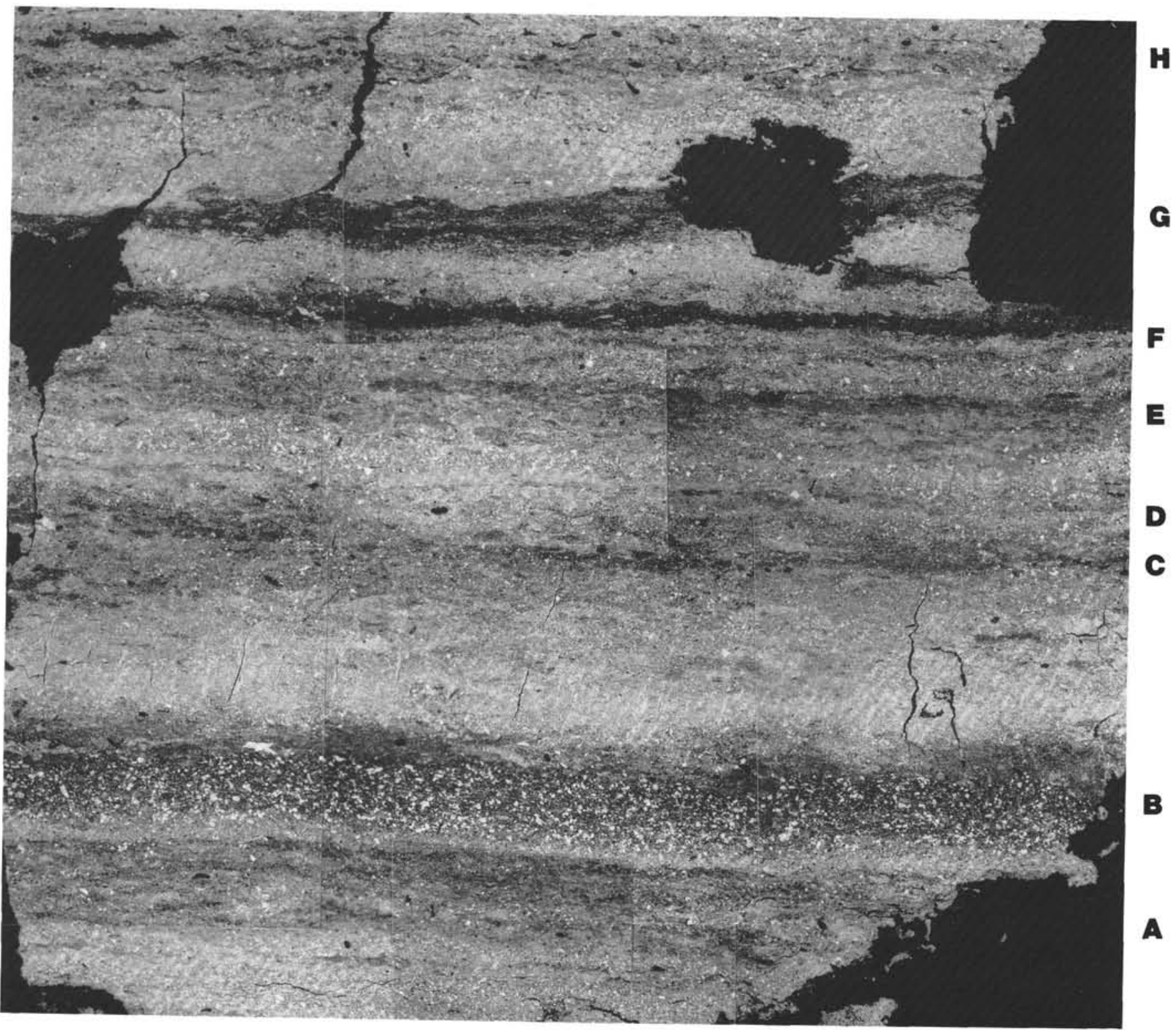

Plate 4. BSEI mosaic showing detail of varve-type lamina facies association in the Quaternary sequence of Site 686 (Sample 112-686B-3H-2, $115-117 \mathrm{~cm})$. The darker laminae and pockets are diatom ooze, and the paler laminae are terrigenous silt and clay, with some admixed which is both vertically and laterally variable inous feldspathic silt layer. Most of the laminae show the effects of some degree of bioturbation, which is both vertically and laterally variable in intensity. In particular, lamina $\mathrm{E}$ becomes almost entirely homogenized from right to left. 

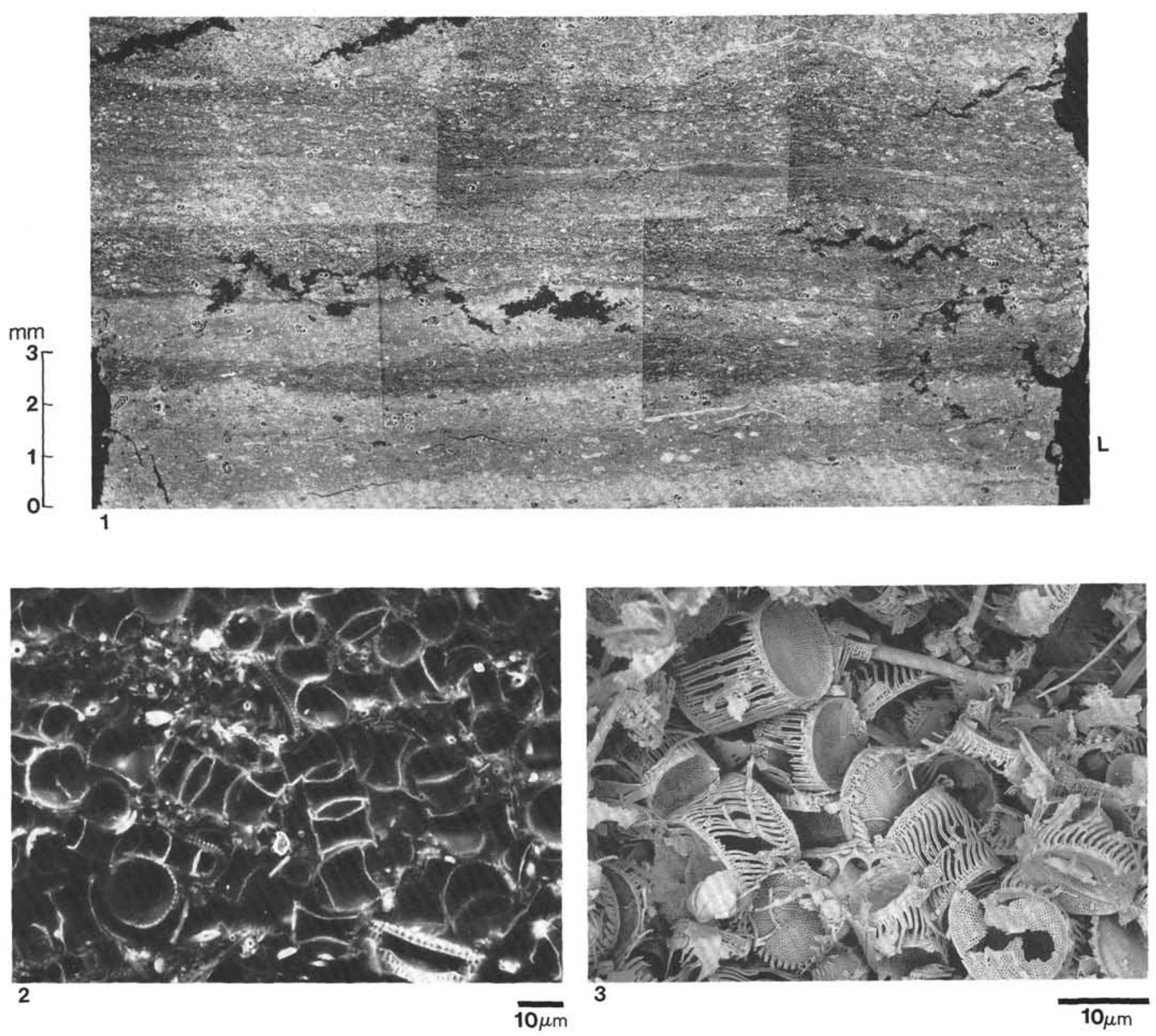

Plate 5. BSEI and SEI of diatom-ooze laminae (Sample 112-680A-2H-1, 103-105). 1. General view of composite diatom-ooze laminae enclosed top and bottom by diatomaceous mud. Several internal sublayers are identifiable even at this relatively low resolution. Individual layers have distinctive compositions. 2, 3. BSE and SE images, respectively, of lamina L, which composes mainly a centric diatom and chaetoceros bristles. 

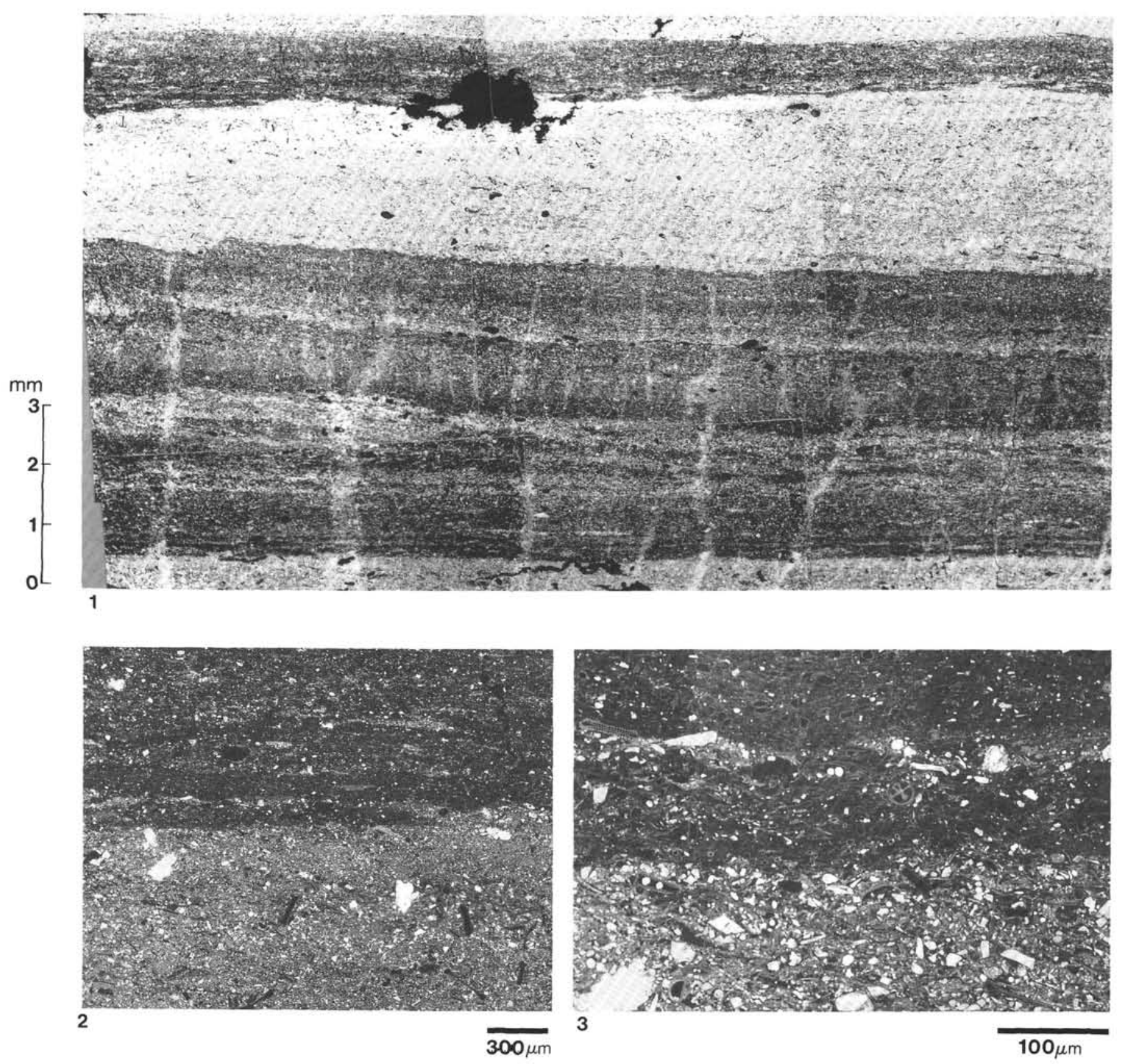

Plate 6. General view and details of mixed-ooze/terrigenous laminae from Site 680 (Sample 112-680B-10H-5, 50-52 cm). 1. Darker ooze laminae have internal microlayers of varying thickness of terrigenous silt that form parallel systems. 2, 3. Detail of discordant microlayering in top left of 1 , which is discussed in the text. Figure 3, which is a detail of the center left of Figure 2, shows the contact between a diatom-ooze lamina overlying diatomaceous mud. An internal microlayer of terrigenous sediment (including some diatom fragments) that varies from 10 to $50 \mu \mathrm{m}$ in thickness and parallels the basal contact. 